\title{
Congresso Brasileiro dos Conselhos de Enfermagem - CBCEnf
}

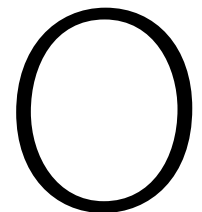

Congresso Brasileiro dos Conselhos de Enfermagem, em sua décima quarta edição, é a consolidação da iniciativa do Cofen em ter um Congresso voltado para toda a categoria de enfermagem. Nele se fazem representar os auxiliares e técnicos de enfermagem e enfermeiros de todas as regiões do país. Os organizadores do evento juntamente com a Comissão Científica se preocuparam em atender às expectativas dos participantes, produzindo um evento que tivesse também uma agenda social e de atrações para lazer, com um custo viável aos profissionais.

Com o tema central: A Dimensão Social da Enfermagem: para além do público e o privado

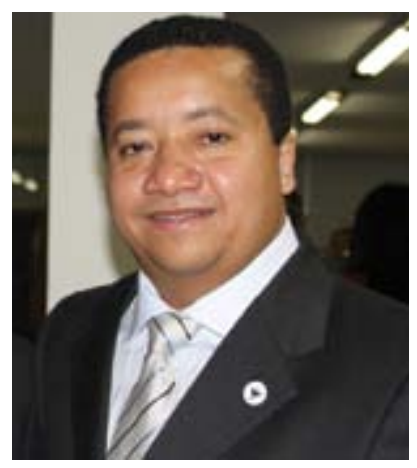
este ano o CBCEnf foi realizado em Curitiba no estado do Paraná. O tema oficial do Congresso determina todos os eixos de discussão. Foram abordadas questões da prática profissional e apresentados resultados de pesquisas, com a participação de eminentes palestrantes. As câmaras técnicas do Conselho apresentaram seus relatórios, promoveram discussões com o público sobre questões atuais que afetam a profissão e como desejado, os aspectos científicos atraíram uma maior massa crítica a participar, pois houve um crescimento na participação de pesquisadores.

O Sistema se fez presente na feira dos Conselhos, com exposição de cada regional demonstrando seu trabalho nos

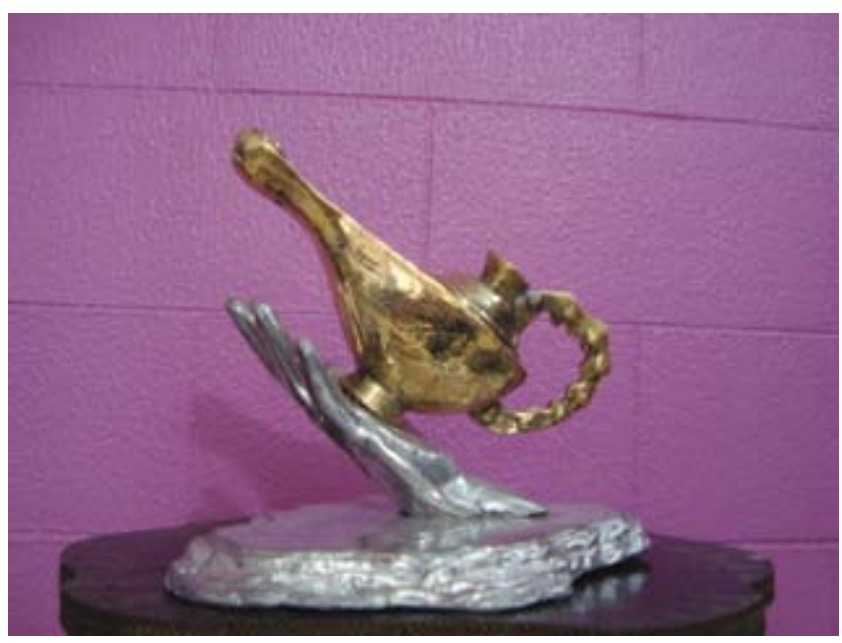

Troféu Anna Nery entregue durante o CBCEnf a 23 personalidades que se destacaram em suas carreiras estados e proporcionando grande interação com o público. Tal exposição possibilitou-nos um retrato do Brasil.

Pela primeira vez, durante esta edição do evento, ocorreu a entrega do prêmio Anna Nery para 23 personalidades que se destacaram em suas carreiras. $\mathrm{O}$ troféu, obra do artista plástico paranaense Luís Galiastri, é uma estilização da mão e a lâmpada de Florence Nightingale, conhecida como a Dama da Lâmpada e símbolo internacional da enfermagem moderna.

Estamos em tempos de celebração, pois já em 11 de setembro o Sistema terá eleições em todas os regionais. Feito que orgulha a enfermagem brasileira que vive um momento de salutar democracia e lealdade nas disputas eleitorais. 